\title{
Risk Zones of Human Leishmaniases in the Western Mediterranean Basin. Correlations between Vector Sand Flies, Bioclimatology and Phytosociology
}

\author{
Philippe Rispail ${ }^{+}$, Jacques Dereure, Daniel Jarry
}

Laboratoire de Parasitologie-Mycologie, Faculté de Médecine de Montpellier-Nîmes et Centre Hospitalier Universitaire de Montpellier, 163 rue Auguste-Broussonet, 34090 Montpellier, France

Correspondence analysis was applied to sand fly sampling in 865 stations from the Western Mediterranean basin. The position of each of 24 species was determined with respect to the bioclimatic belts. Thus, the multidimensional analyses manifest clear correlations between bioclimatic belts and their expression in the area, the phytosociological groupings, and vector species of visceral and cutaneous leishmaniases. The transfer of these data to usual maps allows to delimit the geographical distribution of these diseases in the Western Mediterranean basin and contributes to the determination, in a rational manner, of the high risk zones.

Key words: sand flies - leishmanial foci - bioclimatic belts - phytosociological groupings - correspondence analysis Western Mediterranean basin - Morocco

The leishmaniases are parasitic diseases caused by several species of flagellate Protozoa belonging to the genus Leishmania Ross 1903 and transmitted by the bite of the haematophagous female of a phlebotomine sand fly. Around the Western Mediterranean basin, the animal reservoir hosts of visceral and cutaneous leishmaniases are Canidae and Rodentia. In this geographical area, the vector sand flies are members of the genus Phlebotomus Rondani \& Berté 1840, while some species belonging to the genus Sergentomyia França \& Parrot 1920 are vectors of Leishmania-like parasites of Old World reptiles.

Leishmaniases are an important problem for public health: from 1996 to 1999, about a thousand cases was registered in South Europe and more than 35,000 in North Africa (these data are under-estimated because some countries do not declare leishmaniases); numerous cases were associated with Aids. Moreover, the impact of the climate change induces in Mediterranean countries a risk of increase and an extension of the foci of arthropod-borne diseases (Rhodain 2000).

The importance of phlebotomine sand flies as vectors and as determinants of the structure of foci of leishmaniases, has been known for many years. The route-transect method, which has been used for more than thirty years (Rioux et al. 1982a), has enabled the collection and identification of about 200,000 sand flies in some 2,000 stations spread all around the Western Mediterranean basin. Simultaneous study of the distribution of the vector species, their density and natural environmental factors favourable to their development, contributed to the analysis and prediction of leishmanial foci (Rioux et al. 1969). Such a large amount of information could not be processed

${ }^{+}$Corresponding author. Fax: +33-4-63.0049. E-mail: p-rispail@chu-montpellier.fr

Received 6 June 2001

Accepted 20 February 2002 by monofactorial deterministic methods, but requires multidimensional methods of analysis experimentally before used in North Africa (Rioux et al. 1984b, 1986b, Rispail 1986).

\section{MATERIALS AND METHODS}

Data collection - Maps and field note-books accurately report the route-transects. These transects, carried out in summer (June to September) from 1972 to 1984, covered numerous leishmanial foci of the Western Mediterranean perimeter, in Algeria (Chott Hodna), France (Cévennes, Corsica, Montpellier area, Nice area, Vallespir), Italy (Grossetto area), Morocco (three long transects from humid North to per-arid South), Spain (Catalonia, Valencia area) and Tunisia (northern and Gafsa areas). Trappings were executed by the team of the Laboratoire de Parasitologie-Mycologie, Faculté de Médecine de Montpellier, with the collaboration of many epidemiologists and entomologists from the above-mentioned areas. A minimum of 30 oiled-paper traps, recovered in a good state after three or four nights (Rioux et al. 1982a), allowed the inclusion of 865 stations. A total of 182,813 specimens of 24 species of Phlebotomus and Sergentomyia were identified (Table). Though phytosociological maps actually exist for the periphery of the entire Mediterranean basin, the only phytogeographical map of Emberger $(1936,1939)$ and bioclimatic map of Sauvage (Sauvage \& Brignon 1963), both available solely in Morocco, are enough large-scaled to precisely locate near stations. The availability of these bioclimatological (five belts, from humid to per-arid) and phytosociological data, wide coverage (132,582 sand flies from 353 stations) and the presence of most of the Mediterranean species (21 from 24), led to the choice of Morocco for a special analysis.

Data analysis - The "species" file contained, for each station, the number of traps retrieved and, for each species of sand fly, the number of individuals of each sex. This coding allowed analysis of presence/absence and density of both sexes of each species, together or sepa- 
rately. The "descriptors" file contained the available bioclimatological and phytosociological information. Three tables were analyzed to compare species, descriptors and stations: (1) the species/stations table was either a presence/absence table or the result of the calculation, for each species, of its density (ds) by station corrected according to the formula:

$$
d s=\sqrt{1+\frac{\text { number of sand flies }}{\text { number of traps }} \times 100}
$$

in which use of square root is a mathematical way allowing to reduce the dispersion of the variable without modifying the relative position of the species in the multidimensional space; (2) the stations/descriptors table required a discreet coding of different states of variables; (3) the species/descriptors table recorded the sand flies of each species trapped in the stations distributed in each state of each environmental variable (contingency table).

Following the tabulation of data, analyses were carried out using programmes developed from those of the algorithm Analyses de Données of the software Biomeco
2.0 package (Groupe Biométrie CEPE/CNRS, Montpellier). Unlike the standard statistics, the data analysis is multidimensional. It results in an illustration in which degrees of relationship, resemblances or differences between the elements are expressed. Different representations of the data, notably geometrical representations (as opposed to algebric, for instance hierarchical ascending classification), are possible. Among geometrical representations, the correspondence analysis, extensively developed in France under the title "analyse factorielle des correspondances" (Legendre \& Legendre 1979, Benzécri 1982), is a method of cluster analysis closely related to principal component analysis and particularly well ajusted to qualitative and semi-quantitative data. Linear functions of the indicator variables are chosen in such a way that the multidimensional scatter is most closely approximated by a diagram in a small number of dimensions. The individuals in a particular response category can be represented by a point in this diagram, and it may then be possible to identify interesting clusters of individuals (Armitage \& Berry 1994). So, the information contained in the numerous primary descriptors is reduced to a small

TABLE

Sand flies trapped and identified around the Western Mediterranean basin from 1972 to 1984 . About $65 \%$ were identified as Sergentomyia minuta. Only Phlebotomus ariasi and P. papatasi among vector species of leishmaniases in this area (in bold type) are over $5 \%$

\begin{tabular}{|c|c|c|c|c|c|c|}
\hline & \multicolumn{3}{|c|}{ No. } & \multicolumn{3}{|c|}{$\begin{array}{l}\text { Contributions of species } \\
\text { to the axes (Fig. 1) }\end{array}$} \\
\hline & $\mathrm{E}$ & G & $E+G$ & I & II & III \\
\hline Phlebotomus (Phlebotomus) bergeroti & 9 & 34 & 43 & 9 & 0 & 14 \\
\hline Phlebotomus (Phlebotomus) papatasi & 3,173 & 8,124 & 11,297 & 122 & 0 & 94 \\
\hline Phlebotomus (Paraphlebotomus) alexandri & 873 & 6,763 & 7,636 & 128 & 1 & 11 \\
\hline Phlebotomus (Paraphlebotomus) chabaudi & 83 & 354 & 437 & 17 & 0 & 84 \\
\hline Phlebotomus (Paraphlebotomus) kazeruni & 5 & 57 & 62 & 1 & 0 & 1 \\
\hline Phlebotomus (Paraphlebotomus) sergenti & 1,181 & 2,526 & 3,707 & 25 & 0 & 48 \\
\hline Phlebotomus (Larroussius) ariasi & 2,042 & 11,926 & 13,968 & 193 & 477 & 81 \\
\hline Phlebotomus (Larroussius) chadlii & 3 & 59 & 62 & 0 & 11 & 13 \\
\hline Phlebotomus (Larroussius) langeroni & 7 & 40 & 47 & 0 & 15 & 4 \\
\hline Phlebotomus (Larroussius) longicuspis & 788 & 3,506 & 4,294 & 14 & 1 & 124 \\
\hline Phlebotomus (Larroussius) mariae & 1 & 9 & 10 & 0 & 0 & 3 \\
\hline Phlebotomus (Larroussius) perfiliewi & 117 & 240 & 357 & 21 & 312 & 72 \\
\hline Phlebotomus (Larroussius) perniciosus & 1,511 & 3,967 & 5,478 & 132 & 168 & 56 \\
\hline \multirow[t]{2}{*}{ Phlebotomus (Transphlebotomus) mascittii } & 65 & 91 & 156 & 3 & 4 & 11 \\
\hline & 9,858 & 37,696 & 47,554 & & & \\
\hline Sergentomyia (Sergentomyia) antennata & 568 & 557 & 1,125 & 52 & 1 & 126 \\
\hline Sergentomyia (Sergentomyia) sp. ${ }^{a}$ & 1 & 4 & 5 & 1 & 0 & 0 \\
\hline Sergentomyia (Sergentomyia) fallax & 5,488 & 6,930 & 12,418 & 138 & 0 & 4 \\
\hline Sergentomyia (Sergentomyia) minuta & 60,226 & 58,441 & 118,667 & 54 & 8 & 116 \\
\hline Sergentomyia (Sergentomyia) schwetzi & 0 & 1 & 1 & 0 & 0 & 0 \\
\hline Sergentomyia (Parrotomyia) africana & 2,255 & 298 & 2,553 & 37 & 1 & 106 \\
\hline Sergentomyia (Parrotomyia) lewisi & 5 & 9 & 14 & 4 & 0 & 7 \\
\hline Sergentomyia (Grassomyia) dreyfussi & 79 & 74 & 153 & 15 & 1 & 5 \\
\hline Sergentomyia (Sintonius) christophersi & 102 & 156 & 258 & 24 & 0 & 5 \\
\hline \multirow[t]{3}{*}{ Sergentomyia (Sintonius) clydei } & 13 & 52 & 65 & 10 & 0 & 15 \\
\hline & 68,737 & 66,522 & 135,259 & & & \\
\hline & 78,595 & 104,218 & 182,813 & & 1000 & \\
\hline
\end{tabular}

a: Sergentomyia (Sergentomyia) sp. belonging to bedfordi group, according to Davidson (1990) 
number of factors. Correspondence analysis consequently allowed a global synthesis, conserving maximum information, notably the qualitative information. This multivariate analysis demonstrated relationships among species, among stations, and between species and stations. Four very scarce species (P. mariae, Sergentomyia sp. belonging to bedfordi group, S. lewisi and S. schwetzi) were treated as supplementary elements (no weight in the analysis; only localization in the cloud of points, compared with others species). When data were available, the position of each species with respect to the bioclimatological and phytosociological variables was determined.

\section{RESULTS AND DISCUSSION}

The Western Mediterranean basin - The correspondence analysis ranks the species by station according to their density, in the form of a continuum, along a clear bioclimatic gradient. So, the analysis indicates the interspecific relationships and the position of each species within this bioclimatic continuum. The factorial plan I - II organizes the species from the humid to per-arid belts. The second axis probably expresses, within the species of the humid and sub-humid belts, an ancestral biogeographical separation between $P$. (Larroussius) ariasi Tonnoir 1921 abundant on the Western Mediterranean coast, and P. (Larroussius) perfiliewi Parrot 1930 which has a more oriental situation in the Western Mediterranean basin. The projection of the cloud of points in the plot of axes I and III (Fig. 1), distributes the species along a parabola (artefactual but not disturbing "Guttman effect"), from the upper left humid quarter to the sub-humid, semi-arid and arid lower half, then to the per-arid upper right quarter. Whilst the sand flies of the subgenera Larroussius and Transphlebotomus occupy the humid, sub-humid and semi-arid left quarters, the subgenera Paraphlebotomus and Phlebotomus are distributed in the arid and per-arid right quarters.

These results are closely related to the geographical distribution of visceral and cutaneous leishmaniases in the Western Mediterranean basin. Indeed, P. ariasi (Rioux et al. 1984a) and $P$. (L.) perniciosus Newstead 1911 (Izri et al. 1990) were demonstrated as vectors of visceral and cutaneous leishmaniases due to Leishmania infantum, both from Portugal to Italy and from Morocco to Tunisia, where Canidae are reservoir hosts. L. infantum may be also present in the semi-arid belt in sympatric condition with L. tropica (Dereure et al. 1991), and even in the arid belt (Dereure et al. 1986). In these areas, $P$. (L.) longicuspis Nitzulescu 1930, the only Larroussius present, could be the vector of L. infantum. P. perfiliewi, proven vector in Algeria (Izri \& Belazzoug 1993), is scarce in the South East of France (Izri et al. 1994) and more abundant on the Adriatic coast in Italy (Corradetti 1960). P. (Pa.) sergenti Parrot 1917 was found infected by L. tropica in the semiarid belt in Morocco (Guilvard et al. 1991), and so was shown to be a vector of anthroponotic cutaneous leishmaniasis in this country. $P$. (P.) papatasi (Scopoli 1786) was found to be the vector of L. major (Rioux et al. 1986a), agent of zoonotic cutaneous leishmaniasis in the arid and per-arid belts, from rodent reservoir hosts [Meriones spp. in Morocco (Petter 1988), Algeria (Belazzoug 1986) and Tunisia (Rioux et al. 1986c); Psammomys spp. in Algeria (Belazzoug 1983)] to man.

The example of Morocco - The results indicate that densities of the 21 species are correlated with the same bioclimatic gradient. In the species / bioclimatological and phytosociological factors analysis (Fig. 2), the species are located according to their average density at the stations corresponding to the bioclimatic belts and their expression in the area, the phytosociological groupings (Fig. 3).

Thus, $P$. ariasi is related to the humid and sub-humid bioclimatic belts with Mediterranean oaks as indicators

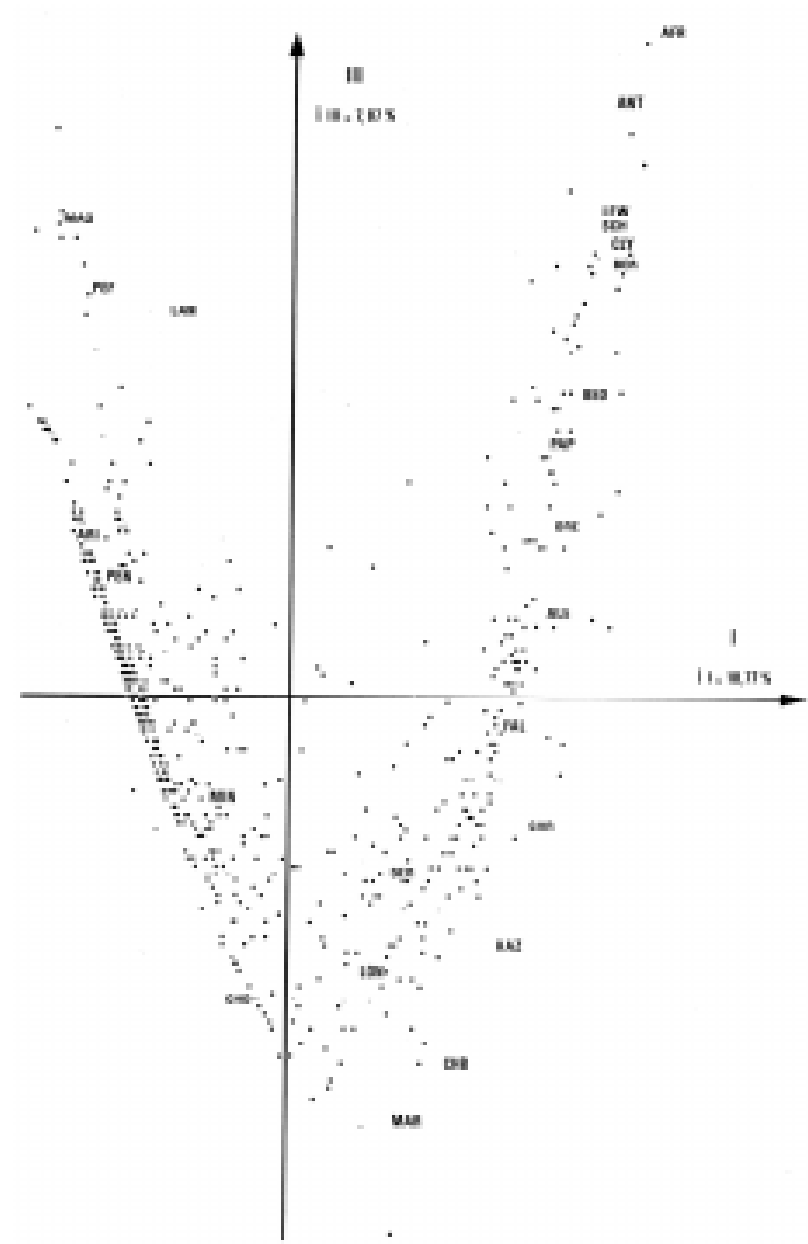

Fig. 1: sand flies of the Western Mediterranean basin. Factorial correspondence analysis species/stations (densities). Projection of the cloud of points in the factorial plan I-III $(26.6 \%$ of the total information). Each spot represents a station. Abbreviated names of species are at the projections of the barycentres of the distribution of each species within a bioclimatic continuum, from the upper left humid quarter to the per-arid upper right quarter. BER: Phlebotomus (Phlebotomus) bergeroti; PAP: P. (P.) papatasi; ALE: P. (Paraphlebotomus) alexandri; CHB: P. (Pa.) chabaudi; KAZ: P. (Pa.) kazeruni; SER: P. (Pa.) sergenti; ARI: P. (Larroussius) ariasi; CHD: $P$. (L.) chadlii; LAN: P. $(L$.$) langeroni; LON: P$. $(L$. longicuspis; MAR: $P$. (L.) mariae; PEF: $P$. (L.) perfiliewi; PEN: $P$. (L.) perniciosus; MAS: P. (Transphlebotomus) mascittii; ANT: Sergentomyia (Sergentomyia) antennata; BED: $S$. (S.) sp. belonging to bedfordi group; FAL: $S$. (S.) fallax; MIN: $S$. (S.) minuta; SCH: $S$. (S.) schwetzi; AFR: $S$. (Parrotomyia) africana; LEW: $S$. (P.) lewisi; DRE: S. (Grassomyia) dreyfussi; CHR: S. (Sintonius) christophersi; CLY: S. (Si.) clydei 


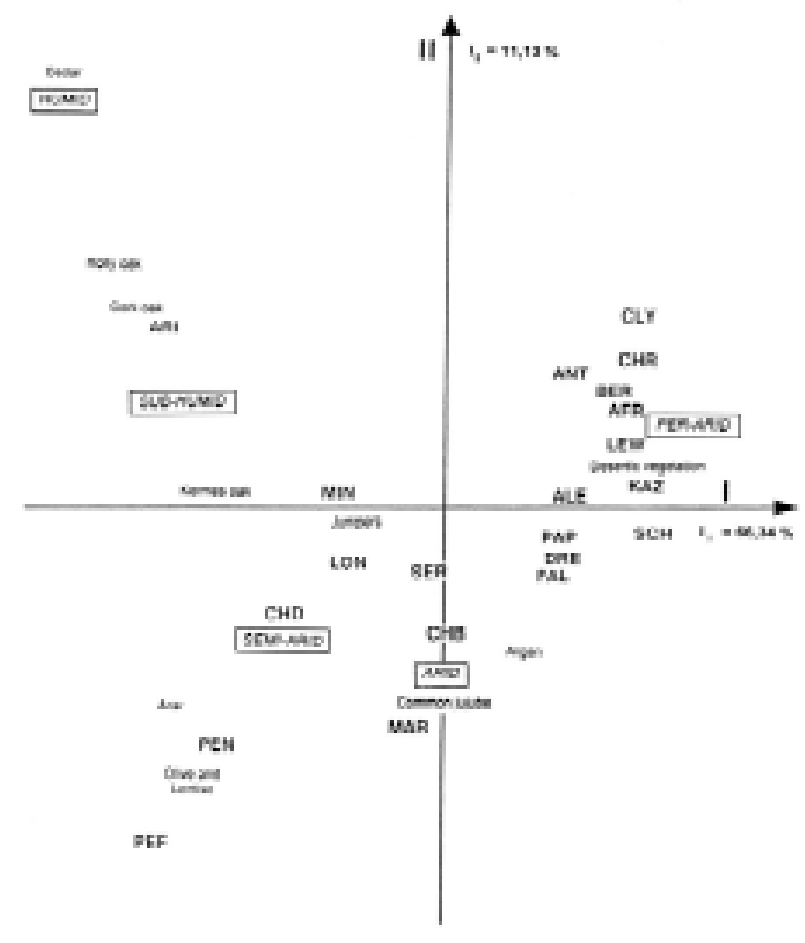

Fig. 2: sand flies of Morocco. Factorial correspondence analysis species/bioclimatological and phytosociological factors. Projection of the cloud of points in the factorial plan I-II $(77.5 \%$ of the total information). Sand fly species - bioclimatic belts - phytosociological groupings relationships. Bioclimatic belts according to Sauvage are in italic capitals. Phytosociological groupings according to Emberger are in roman types. Abbreviated names of species are at the projections of the barycentres of the distribution of each species. BER: Phlebotomus (Phlebotomus) bergeroti; PAP: P. (P.) papatasi; ALE: P. (Paraphlebotomus) alexandri; CHB: P. (Pa.) chabaudi; KAZ: $P$. (Pa.) kazeruni; SER: P. (Pa.) sergenti; ARI: P. (Larroussius) ariasi; CHD: P. (L.) chadlii; LAN: P. (L.) langeroni; LON: $P$. (L.) longicuspis; MAR: P. (L.) mariae; PEF: P. (L.) perfiliewi; PEN: P. (L.) perniciosus; MAS: P. (Transphlebotomus) mascittii; ANT: Sergentomyia (Sergentomyia) antennata; BED: S. (S.) sp. belonging to bedfordi group; FAL: $S$. (S.) fallax; MIN: $S$. (S.) minuta; SCH: S. (S.) schwetzi; AFR: S. (Parrotomyia) africana; LEW: S. (P.) lewisi; DRE: S. (Grassomyia) dreyfussi; CHR: S. (Sintonius) christophersi; CLY: S. (Si.) clydei

(Fig. 4A). In these areas, L. infantum is the agent of human visceral and cutaneous leishmaniases (Fig. 4B), from the Mediterranean coast (Rif mountains) to the Souss plain and from Atlantic coast to Moyen-Atlas chain. Epidemiologically, the dog is known as the common reservoir host of $L$. infantum and $P$. ariasi as the vector (Rioux et al. 1979). Moreover, Killick-Kendrick and Killick-Kendrick (1999) suggested "that the apparent specialisation in honeydew feeding perhaps limits the distribution of $P$. ariasi to that of Lachnus roboris", aphid which infests leaves of Quercus ilex. Some other restricted foci, related to adequate microclimate, could be favorable to development of L. infantum. So, in Issafen (Anti-Atlas chain, in the arid bioclimatic area), one autochtonous case of canine visceral leishmaniasis due to L. infantum MON-1 was reported (Dereure et al. 1986). Also, in Taghjicht oasis (per- arid belt) in Southern Morocco, several cases of human cutaneous leishmaniasis were related to L. infantum MON-24 (Rioux et al. 1997). In these two areas, $P$. longicuspis is present and could be the vector.

$P$. sergenti is related to the semi-arid bioclimatic belt where the vegetation is characterized by arar (Tetraclinis articulata) and junipers (Juniperus spp.) (Fig. 5A), and to a lesser degree, to the arid belt, by argan (Argania spinosa) and common jujube (Ziziphus lotus). Anthroponotic cutaneous leishmaniasis due to L. tropica (Fig. 5B) is common in these areas: in Tanent (northern slope of the Haut-Atlas mountain) and Smimou (at the western extremity of the chain) (Pratlong et al. 1991). The epidemiological cycle is commonly considered as anthroponotic, although several cases of canine cutaneous leishmaniasis due to L. tropica were reported in these two foci (Dereure et al. 1991), where P. sergenti was demonstrated as the vector (Guilvard et al. 1991). It is also important to note that Tanent (Azilal area) is a mixed focus where L. tropica in man and L. infantum in dog are sympatric (Dereure et al. 1991). As above-mentioned, $P$. longicuspis is present with $P$. sergenti in this focus, and could be the vector of $L$. infantum. Moreover, several cases of human cutaneous leishmaniasis due to L. tropica were described in North of Morocco, near Taza, at the junction

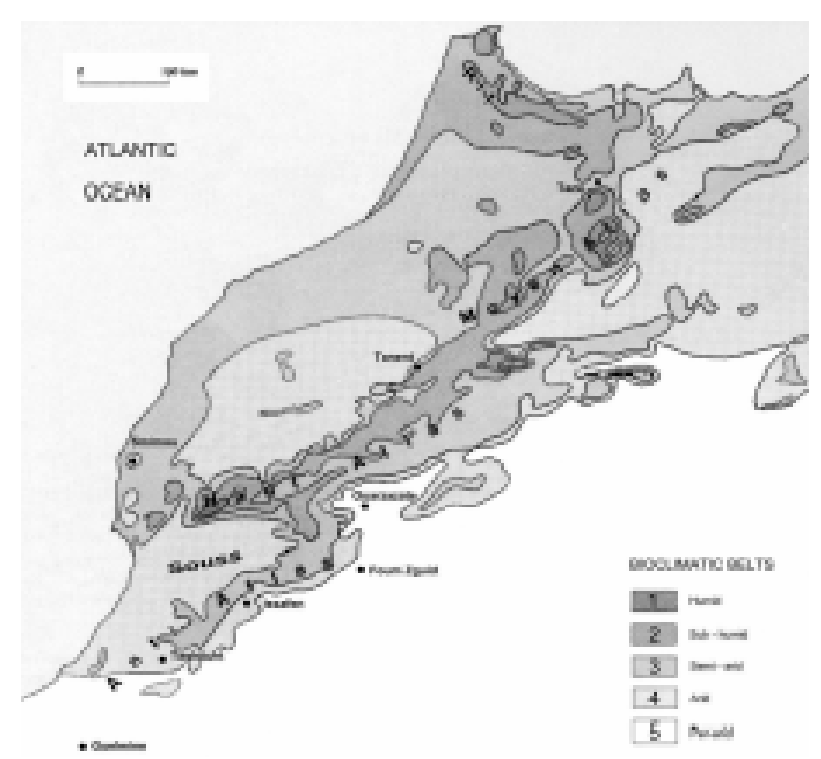

Fig. 3: Morocco. Bioclimatic map according to Sauvage and Brignon 1963 (adapted from Rioux et al. 1984b). Correlations between bioclimatic belts, phytosociological groupings according to Emberger (1936, 1939), vector sand flies and leishmaniases. (1) Humid belt (Cedrus atlantica) and (2) sub-humid belt (Quercus coccifera, $Q$. ilex): distribution areas of Phlebotomus ariasi, vector of zoonotic visceral and cutaneous leishmaniases due to Leishmania infantum. (3) Semi-arid belt (Tetraclinis articulata, Juniperus spp., Olea europaea, Pistacia spp.): distribution area of P. sergenti, vector of anthroponotic cutaneous leishmaniasis due to L. tropica. (4) Arid belt (Argania spinosa, Ziziphus lotus) and (5) per-arid belt (Atriplex spp. and other Saharian vegetation): distribution areas of $P$. papatasi, vector of zoonotic cutaneous leishmaniasis due to $L$. major. This type of map is useful for studies about diseases transmitted by vector correlated with bioclimatic belts. It can be to predictive value for some diseases in bioclimatic areas included inside an other belt. 


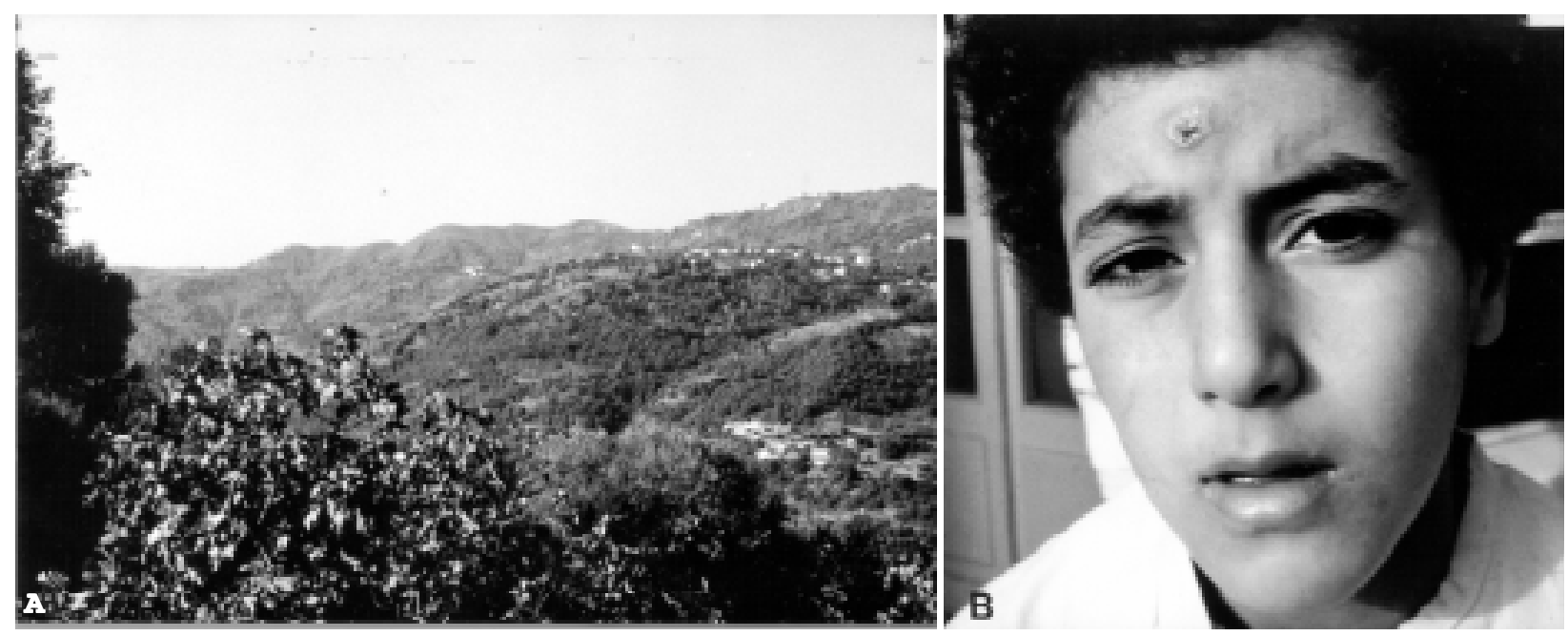

Fig. 4: sub-humid bioclimatic belt in North Morocco. A: mountainous landscape in the Rif chain. Phytosociological grouping: mixed oaks (Quercus ilex and Q. pubescens), typical biotope of Phlebotomus ariasi. B: zoonotic cutaneous leishmaniases due to Leishmania infantum.
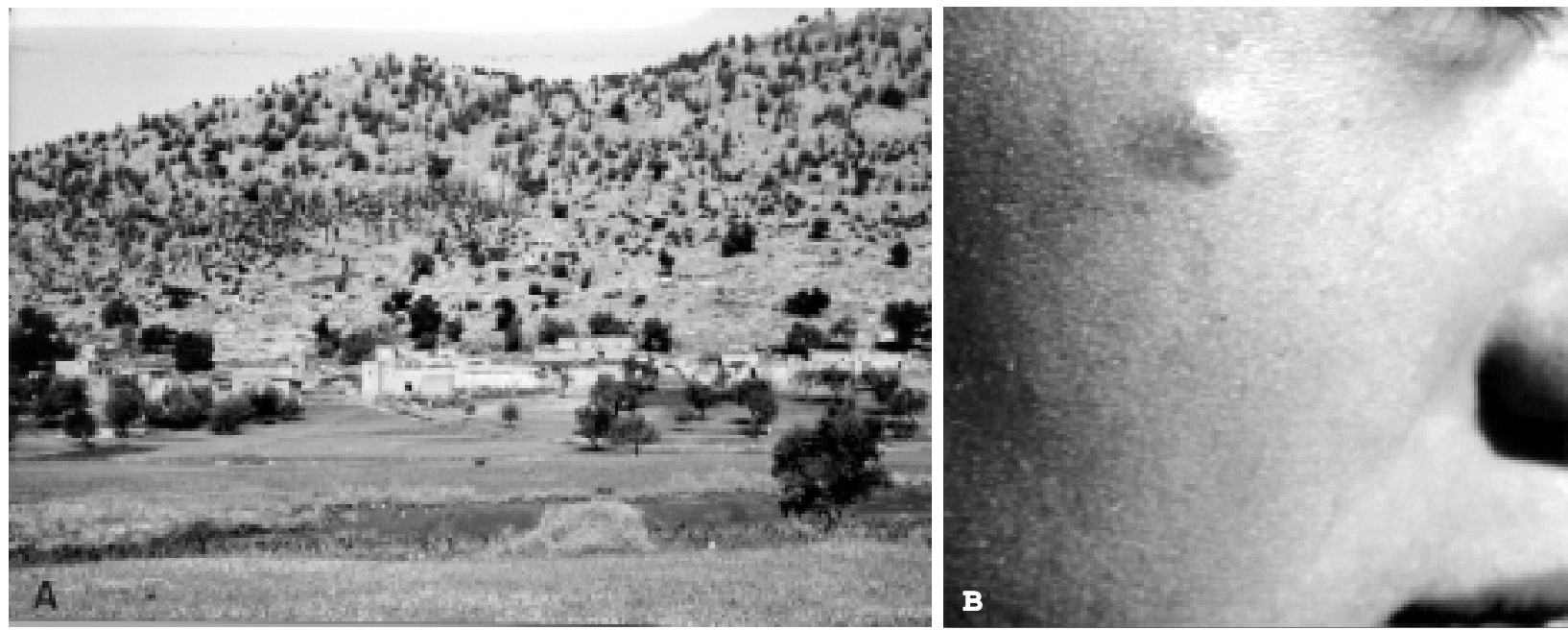

Fig. 5: semi-arid bioclimatic belt in Moroccan Haut-Atlas. A: village in Tanent area. Phytosociological grouping: arar (Tetraclinis articulata) and junipers (Juniperus spp.), typical biotope of Phlebotomus sergenti. B: anthroponotic cutaneous leishmaniasis due to Leishmania tropica.

of the eastern part of Rif mountain and the western part of Moyen-Atlas chain (Guessous-Idrissi et al. 1997b). One case of canine visceral leishmaniasis, also due to $L$. tropica, was described in this area, where T. articulata is present and signifies semi-arid bioclimatic belt (GuessousIdrissi et al. 1997a).

$P$. papatasi, proved as the vector of $L$. major (Rioux et al. 1986a), occurs in the arid and principally per-arid bioclimatic belts, the second one with desertic vegetation and Saharian flora (Atriplex spp., ...) (Fig. 6A). Moreover, Schlein and Warburg (1986) showed that laboratory-bred $P$. papatasi of both sexes pierce leaves or stems of the per-arid caper plant (Capparis spinosa). This per-arid area has been known for long-time as a focus of zoonotic cutaneous leishmaniasis due to L. major (Fig. 6B), from Guelmime to Foum Zguid (Rioux et al. 1986b) and in the Ouarzazate area (unpublished data). The common reser- voir is constitued by rodents of the genus Meriones (Rioux et al. 1982b).

In conclusion we can say that one essential feature of each focus of leishmaniasis is the vector which has requirements which determine its distribution. The eco-epidemiological multidimensional analyses are a very useful synthesis tool and show clear correlations between vector species, bioclimatic belts and phytosociological groupings. The bioclimatic and phytological requierements for each sand fly species can be easily transferred to usual maps and therefore, allow to delimit the geographical distribution of cutaneous and visceral leishmaniases in the Western Mediterranean basin. Thus, these analyses contribute to the definition of the structure of the leishmanial foci and to the determination, in a rational manner, of the high risk zones of these infections. The simultaneous presence of a known vector and a known reservoir for the 

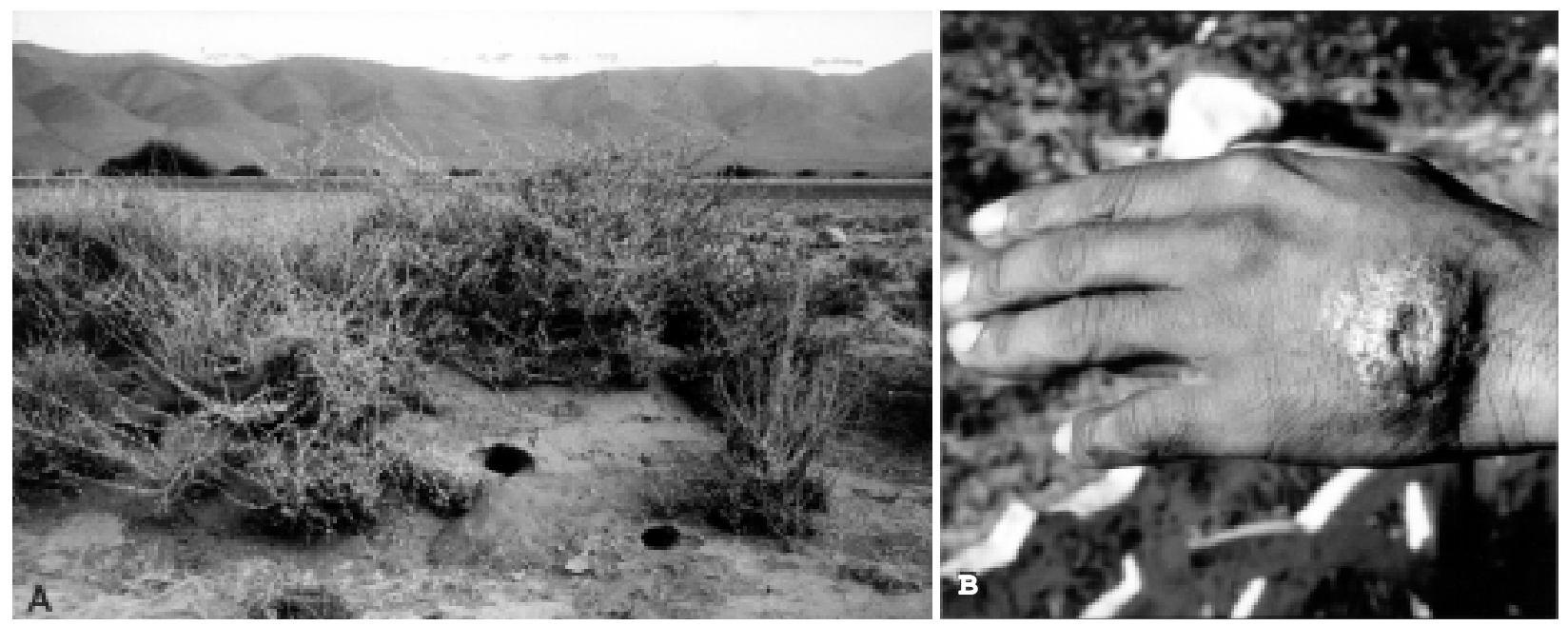

Fig. 6: per-arid bioclimatic belt in South Morocco. A: desertic landscape. Phytosociological grouping: Atriplex spp. and other Saharian vegetation, typical biotope of Phlebotomus papatasi. Burrows of reservoir rodents are visible. B: zoonotic cutaneous leishmaniasis due to Leishmania major.

same Leishmania can be considered as a predictional factor of possible occurence of outbreaks of leishmaniasis. Conversely, the verified absence of the vector, even if the reservoir is present in the area, is an absolute factor of security. The implementation of prevention and control are thereby made possible.

\section{ACKNOWLEDGMENTS}

To J-A Rioux who was the head of this laboratory and masterly responsible for the orientation of the eco-epidemiological surveys on leishmaniases from 1972 to 1984 . The results presented in this paper have benefitted from the captures in natura and the identifications by many entomologists, particularly: J-C Beaucournu, A Chabaud, H Croset, J-P Dedet, A Delalbre-Belmonte, J and M Gallego, E Guilvard, R Houin, DT Jarry, R and M Killick-Kendrick, G Lanotte, N Léger, R Maazoun, M Maistre, A Martini, G Moreno, J Périères, M Portus, F Pratlong, R Teissier and ID Velez. To RW Ashford (Liverpool School of Tropical Medicine), M Roux (Faculté des Sciences, Marseille), and E Serres (Faculté de Médecine, Montpellier-Nîmes) for their valuable advice.

\section{REFERENCES}

Armitage P, Berry G 1994. Statistical Methods in Medical Research, Blackwell Scientific Publications, Oxford \& Boston, $620 \mathrm{pp}$.

Belazzoug S 1983. Isolation of Leishmania major Yakimoff \& Schokhor, 1914 from Psammomys obesus Gretzschmar, 1828 (Rodentia Gerbillidae) in Algeria. Trans R Soc Trop Med Hyg 77: 876.

Belazzoug S 1986. Découverte d'un Meriones shawi (Rongeur, Gerbillidé) naturellement infesté par Leishmania dans le nouveau foyer de leishmaniose cutanée de Ksar Chellala (Algérie). Bull Soc Path Exot 79: 630-633.

Benzécri JP 1982. L'Analyse des Données. II. L'Analyse des Correspondances, Dunod, Paris, 632 pp.

Corradetti A 1960. I focolai italiani di kala azar e il problema della leishmaniosi nel Sud Europa. Parassitologia 2: 95-98.

Davidson IH 1990. Sandflies of Africa South of the Sahara. Taxonomy and Systematics of the Genus Sergentomyia, South African Institute for Medical Research,
Johannesburg, $78 \mathrm{pp}$.

Dereure J, Rioux JA, Gallego M, Périères J, Pratlong F, Mahjour J, Saddiki H 1991. Leishmania tropica in Morocco: infection in dogs. Trans R Soc Trop Med Hyg 85: 595.

Dereure J, Velez ID, Pratlong F, Denial M, Lardi M, Moreno G, Serres E, Lanotte G, Rioux JA 1986. La leishmaniose viscérale autochtone au Maroc méridional. Présence de Leishmania infantum MON-1 chez le Chien en zone présaharienne. In Leishmania. Taxonomie et Phylogenèse. Applications Eco-épidémiologiques, Int Coll CNRS/ INSERM/OMS (2-6 July 1984), Institut Méditerranéen d'Etudes Epidémiologiques et Ecologiques, Montpellier, p. 421-425.

Emberger L 1936. Présentation de la carte phytogéographique du Maroc au 1/1500000. C R Séanc Mens Soc Sci Nat Phys Maroc 4: 28-29.

Emberger L 1939. Aperçu général sur la végétation du Maroc. Commentaire de la carte phytogéographique du Maroc 1:1500000. Veröff Geobot Instit, Eidgen Techn Hochsch Rübel Zürich 14: 40-157.

Guessous-Idrissi N, Berrag B, Riyad M, Sahibi H, Bichichi M, Rhalem A 1997a. Leishmania tropica: etiologic agent of a case of canine visceral leishmaniasis in northern Morocco. Am J Trop Med Hyg 57: 172-173.

Guessous-Idrissi N, Chiheb S, Hamdani A, Riyad M, Bichichi M, Hamdani S, Krimech A 1997b. Cutaneous leishmaniasis: an emerging epidemic focus of Leishmania tropica in north Morocco. Trans R Soc Trop Med Hyg 91: 660-663.

Guilvard E, Rioux JA, Gallego M, Pratlong F, Mahjour J, Martinez-Ortega E, Dereure J, Saddiki A, Martini A 1991. Leishmania tropica au Maroc. III - Rôle vecteur de Phlebotomus sergenti. A propos de 89 isolats. Annals Parasitol Hum Comp 66: 96-99.

Izri MA, Belazzoug S 1993. Phlebotomus (Larroussius) perfiliewi naturally infected with dermotropic Leishmania infantum at Tenes, Algeria. Trans R Soc Trop Med Hyg 87: 399.

Izri MA, Belazzoug S, Boudjebla Y, Dereure J, Pratlong F, Delalbre-Belmonte A, Rioux JA 1990. Leishmania infantum MON-1 isolé de Phlebotomus perniciosus, en Kabylie (Algérie). Annals Parasitol Hum Comp 65: 151-152.

Izri MA, Marty P, Fauran P, Le Fichoux Y, Rousset JJ 1994. 
Phlebotomus perfiliewi Parrot, 1930 (Diptera, Psychodidae) dans le Sud-Est de la France. Parasite 1: 286.

Killick-Kendrick R, Killick-Kendrick M 1999. Biology of sand fly vectors of Mediterranean canine leishmaniasis. In $\mathrm{Ca}$ nine Leishmaniasis: an Update, Proc Intern Canine Leishmaniasis Forum, Barcelona, p. 26-31.

Legendre L, Legendre P 1979. Ecologie Numérique. 1. Le Traitement Multiple des Données Ecologiques, Collection Ecologie 12, Masson, Paris, 260 pp.

Petter F 1988. Epidémiologie de la leishmaniose cutanée dans le sud du Maroc et dans le sud-est de l'Arabie. Bull Acad Vét Fr 61: 113-117.

Pratlong F, Rioux JA, Dereure J, Mahjour J, Gallego M, Guilvard E, Lanotte G, Périères J, Martini A, Saddiki A 1991. Leishmania tropica au Maroc. IV - Diversité isozymique intrafocale. Annals Parasitol Hum Comp 66: 100-104.

Rhodain F 2000. Impacts sur la santé: le cas des maladies à vecteurs. In Impacts Potentiels du Changement Climatique en France au XXI siècle, Mission interministérielle de l'effet de serre, Ministère de l'aménagement du territoire et de l'environnement, Paris, p. 122-127.

Rioux JA, Akalay O, Périères J, Dereure J, Mahjour J, Le Houérou HN, Léger N, Desjeux P, Gallego M, Saddiki A, Barkia A, Nachi H 1997. L'évaluation écoépidémiologique du "risque leishmanien" au Sahara atlantique marocain. Intérêt heuristique de la relation "Phlébotomes-bioclimats". Ecol Mediterr 23: 73-92.

Rioux JA, Golvan YJ, Croset H, Tour S, Houin R, Abonnenc E, Petitdidier M, Vollhardt Y, Dedet JP, Albaret JL, Lanotte G, Quilici M 1969. Epidémiologie des Leishmanioses dans le Sud de la France, Monographie 37, Institut National de la Santé et de la Recherche Médicale, Paris, 223 pp.

Rioux JA, Guilvard E, Dereure J, Lanotte G, Denial M, Pratlong F, Serres E, Belmonte A 1986a. Infestation naturelle de Phlebotomus papatasi (Scopoli, 1786) par Leishmania major MON-25. A propos de 28 souches isolées dans un foyer du Sud marocain. In Leishmania. Taxonomie et Phylogenèse. Applications Eco-épidémiologiques, Int Coll CNRS/ INSERM/OMS (2-6 July 1984), Institut Méditerranéen d'Etudes Epidémiologiques et Ecologiques, Montpellier, p. 471-480.

Rioux JA, Jarry DM, Lanotte G, Maazoun R, Killick-Kendrick R 1984a. Ecologie des leishmanioses dans le sud de la France. 18. Identification enzymatique de Leishmania infantum Nicolle, 1908, isolé de Phlebotomus ariasi Tonnoir, 1921 spontanément infesté en Cévennes. Annals Parasitol Hum Comp 59: 331-333.

Rioux JA, Killick-Kendrick R, Leaney AJ, Young CJ, Turner DP, Lanotte G, Bailly M 1979. Ecologie des leishmanioses dans le sud de la France. 11. La leishmaniose viscérale ca- nine: succès de la transmission expérimentale "Chien $\rightarrow$ Phlébotome $\rightarrow$ Chien" par la piqûre de Phlebotomus ariasi Tonnoir, 1921. Annals Parasitol Hum Comp 54: 401-407.

Rioux JA, Lanotte G, Petter F, Dereure J, Akalay O, Pratlong F, Velez ID, Fikri NB, Maazoun R, Denial M, Jarry DM, Zahaf A, Ashford RW, Cadi-Soussi M, Killick-Kendrick R, Ben Mansour N, Moreno G, Périères J, Guilvard E, Zribi M, Kennou MF, Rispail P, Knechtli R, Serres E 1986b. Les leishmanioses cutanées du bassin Méditerranéen occidental. De l'identification enzymatique à l'analyse écoépidémiologique. L'exemple de trois "foyers", tunisien, marocain et français. In Leishmania. Taxonomie et Phylogenèse. Applications Eco-épidémiologiques, Int Coll CNRS/INSERM/OMS (2-6 July 1984), Institut Méditerranéen d'Etudes Epidémiologiques et Ecologiques, Montpellier, p. 365-395.

Rioux JA, Périères J, Killick-Kendrick R, Lanotte G, Bailly M 1982a. Ecologie des leishmanioses dans le Sud de la France. 17. Echantillonnage des phlébotomes par le procédé des pièges adhésifs. Comparaison avec la technique de capture sur appât humain. Annals Parasitol Hum Comp 57: 631-635.

Rioux JA, Petter F, Akalay O, Lanotte G, Ouazzani A, Seguignes M, Mohcine A 1982b. Meriones shawi (Duvernoy, 1842) [Rodentia, Gerbillidae], réservoir de Leishmania major Yakimoff et Schokhor, 1914 [Kinetoplastida, Trypanosomatidae] dans le Sud marocain. CR Hebd Séanc Acad Sci, Paris 294: 515-517.

Rioux JA, Petter F, Zahaf A, Lanotte G, Houin R, Jarry D, Périères J, Martini A, Sarhani S 1986c. Isolement de Leishmania major Yakimoff et Schokhor, 1914 [KinetoplastidaTrypanosomatidae] chez Meriones shawi shawi (Duvernoy,1842) [Rodentia-Gerbillidae] en Tunisie. Annals Parasitol Hum Comp 61: 139-145.

Rioux JA, Rispail P, Lanotte G, Lepart J 1984b. Relations phlébotomes-bioclimats en écologie des leishmanioses. Corollaires épidémiologiques. L'exemple du Maroc. Bull Soc Bot Fr 131: 549-557.

Rispail P 1986. Ecologie des Leishmanioses du Bassin Méditerranéen Occidental. Apport de l'Analyse des Données (Analyse Factorielle des Correspondances et Classification Ascendante Hiérarchique) à l'Écologie des Phlébotomes Vecteurs, Dipl. Etudes Approf. Sci. Evol. Ecol., Univ. Sci. Tech. Languedoc, Montpellier, $50 \mathrm{pp}$.

Sauvage C, Brignon C 1963. Etages bioclimatiques. In Atlas du Maroc, section II, carte 6b. Notice explicative par $C$. Sauvage, Comité National de Géographie du Maroc, Rabat, p. $1-44$.

Schlein Y, Warburg A 1986. Phytophagy and the feeding cycle of Phlebotomus papatasi (Diptera : Psychodidae) under experimental conditions. J Med Entomol 23: 11-15. 
484 Bioclimatology, Phytosociology and Sand Flies - Philippe Rispail et al. 